\section{Analysis of the effects of conservatism in accounting information after the 2011 change in the basic conceptual pronouncement}

\author{
Clóvis Antônio Kronbauer \\ University of Vale do Rio dos Sinos, Postgraduate Program in \\ Accounting Sciences, São Leopoldo, Brazil \\ Luiz Henrique Figueira Marquezan \\ Federal University of Santa Maria, Accounting Sciences Department, \\ Santa Maria, Brazil \\ Marco Aurélio Gomes Barbosa \\ Federal University of Rio Grande, Institute of Economic, \\ Administrative and Accounting Sciences, Rio Grande, Brazil

\section{Carlos Alberto Diehl} \\ University of Vale do Rio dos Sinos, Postgraduate Program in \\ Accounting Sciences, São Leopoldo, Brazil
}

\begin{abstract}
Purpose - This study researches whether the change in NBC TG, promoted in 2011, that excluded Prudence (Conservatism), had any effect on companies' accounting information.
\end{abstract}

Design/methodology/approach - Quantitative approach, using a linear regression based on the Basu (1997) method, Wilcoxon tests and $t$ test, on a sample with 109 companies, listed on the BM\&FBovespa, from 2008 to 2013.

Findings - The results indicate that conservatism is present in accounting for the entire period, and changes do not occur in this feature of the accounting information as of 2011.

Originality/value - This research reinforces the perception of the superiority of economic interest, in particular for possible tax gains, to the detriment of accounting information quality, be it of regulatory origin or another.

Keywords - Conservatism; prudence; basic conceptual pronouncement; accounting standard.
Received on

$01 / 27 / 2016$

Approved on

$02 / 10 / 2017$

Responsible editor:

Prof. Dr. Ivam Ricardo Peleias

Evaluation process:

Double Blind Review

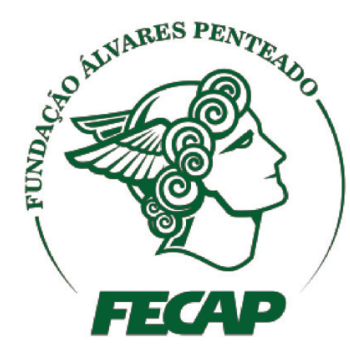

Review of Business Management 


\section{Introduction}

On December 2, 2011, the Accounting Pronouncements Committee (CPC) published the approval term of the Basic Conceptual Pronouncement (R1), confirmed by the Federal Accounting Council (CFC) by the Brazilian Accounting Standard (NBC TG), with changes applicable to the conceptual framework for the preparation and dissemination of accounting and financial reports. One of the amendments is the withdrawal of the characteristic prudence, or conservatism, from the condition of reliable representation, being it inconsistent with neutrality, as it promotes asset undervaluation and liability overvaluation (CPC, 2011).

The concept of conservatism is that profit should not be anticipated, but should anticipate the acknowledgement of all losses (Watts, 2003a). The dynamics of identification of the accounting information, presented in the seminal study of Basu (1997), verifies the reflection of good and bad news and its effect in the results. In the evolution of accounting concepts, although normative, regulation reveals the influence of conservatism (Crawford, Rountree \& Price, 2010), providing new evidence and opportunities for studies (Watts, 2003b).

In Brazil, the change related to conservatism pronounced by the CPC may have influence on the companies' practices and, consequently, possible effects on asset and liability items, mainly in equity from the impact on profits. This argument, which is the basis for this study, is founded on the opportunism of managers and the ensuing associated risks (Hendriksen, 1982), arising from inconsistencies, arbitrariness, cover-ups and contradictions (Kan, 1990) in accounting disclosure. The effects on the accounting information in the absence of prudence can raise the levels of assets, net income and equity, and reduce liabilities, reflecting the interpretation of analysts of financial statements. Therefore, it is necessary to identify whether the companies altered their accounting practices from 2011 onwards.
This study seeks to evaluate whether the change in accounting conceptual framework, removing the information's prudence (conservatism) characteristic, resulted in effects on the financial statements issued by public companies listed on the BM\&FBovespa. This study follows up on the work of Santos et al. (2011) that aims to evaluate the effects of Law $11.638 / 07$ on the conservatism of companies. From the change of perception on conservatism, it is necessary, or at least interesting, to obtain a new verification that may promote the comparability between different time scenarios.

This study has this initial section, with a review on conservatism literature, from its origin to the international and national previous studies, presenting data and results. Ending the study, the final considerations and references.

\section{Theoretical reference}

\section{I Conservatism in accounting theory and norms}

The perception of conservatism in accounting dates back to ancient periods in the history of society, regarding its accounting organization. The first verifications occurred in the medieval period with the validation of the property owner's accounts by auditing as "faithful and prudent". Subsequently, they happened in Italy, with the valuation of assets, mainly inventories, with a lower cost or market value. They were inserted into accounting textbooks in the $17^{\text {th }}$ century, and were hereafter required by the commercial code in France in 1673, Prussia, 1794 and Germany, 1884. Conservatism can be considered one of the oldest good auditing practices (Basu, 2009).

Matthessich (1964) perceived that conservatism, established informally in the accounting practices, where the base cost, representing the amount paid for the asset at the date of acquisition was subject to a reduction in its value due to use, depletion, obsolescence, among others, through periodic cumulative depreciation; 
such a decline was caused by conservative assessment, allowing for adjustment only in cases of original value decline. This allowed other occasional adjustments in asset value, generating significant changes when considering future losses in advance.

Hendriksen (1982) believes the uncertainties represent the basis for a concept of conservatism in traditional accounting. Although it is not an accounting principle, conservatism focuses on its operating medium, which serves as a restriction on the data. The term conservatism requires accounting professionals to report the lowest possible values for the assets and income, and the greatest possible values for liabilities and expenses, in the same way that the costs and losses must be recognized earlier than revenues and earnings.

At the heart of this practice lays the thought that pessimism is assumed to be better than optimism in financial information. Hendriksen (1982) presents three arguments for the existence of conservatism: (i) the tendency for pessimism is assumed to be necessary to counterbalance the natural optimism of managers and owners; (ii) the overstatement of profits and ratings are more dangerous for business; (iii) accounting professionals have access to much more information that can be communicated to investors and creditors, and these professionals assume two types of risk: the information passed on can be considered false later, or the information not passed on is true in the future.

The discussion of accounting conservatism reveals some of the features previously described, but also promotes the argumentation for some criticism. Kan (1990) presents six critical conservatism features: (i) inconsistency - may promote inconsistencies in the measurement of profit; (ii) arbitrariness - political interests can motivate a greater or lesser degree of conservatism, adjusting adequately to specific interests; (iii) cover-ups - there is no way to determine how conservative accounting is, and it places the investor at a disadvantage; (iv) contradiction with accounting principles, for example, regarding the timeliness of information; (v) bias - promotes a systematic bias in the accounting information damaging a realistic assessment; (vi) state of mind - conservatism is strongly present in the professional culture in their attitudes, more than in the uncertainties.

Kan (1990) in contrast to criticism establishes relevant arguments for the defense of conservatism. One of the arguments relates the relevance to dampen the effects of optimism; the second argument concerns the relevance of conservatism for the conformity of statement analysis, as it becomes a rational pathway for reducing information risks. For creditors, the relevance of conservatism is in the disclosure of pertinent information in the identification of adverse consequences.

In Brazil, Iudícibus (2009) points out two different approaches. In the first, considered nobler, conservatism should be understood as a vocational element of the profession, working in the discipline of enthusiasm; the other causes distortions that are based on the principle earlier presented of the cost ratio or market, whichever is lower. Additionally, Iudícibus (2009, p. 64) states that "the great problem of illogical and extreme application of conservatism is that there is a natural tendency among professionals to consider it as the freedom to always present users with the information or variant that presents the lowest profit or the highest liability." The author also emphasizes that the combined application of conservatism and objectivity can diminish relevance if misunderstood. Thus, the preferred critical test for the adoption of a standard should be relevance.

In the normative field, FASB (2008) characterizes conservatism as being the prudent reaction to try to ensure that the uncertainty and risks inherent to the business situation are adequately considered. IASB (2005) understands that conservatism is the inclusion of a degree of precaution in the necessary judgments in making the estimates of uncertainty, so that the assets or 
income are not overvalued and the liabilities or expenses are not underestimated.

In Brazil, the CFC determined prudence, a synonym of conservatism, as a qualitative characteristic of reliability. However, motivated by the considerations of the International Accounting Standards Board (IASB) and some theoretical studies such as Hendriksen (1982) and Kan (1990), the Brazilian Accounting Standard of Conceptual Framework (NBC TG) revoked this condition as it realized a direct conflict with what recommends the characteristic of neutrality (CFC, 2011).

\subsection{Preliminary studies related to conservatism}

In the academic field, one of the most cited papers in conservatism is Basu (1997), in which the author seeks to identify how the results reflect bad news (losses) more quickly than good news (earnings) in the accounting result. Based on a quantitative contribution, the study presents the following results: (i) through the actions of the companies it was verified that the sensitivity to negative news presents a ratio of two to six times the return of positive news; (ii) changes in negative gains are less persistent than the response to positive gains; (iii) Earnings Response Coefficients (ERCs) are greater for positive changes than for negative outcomes, generating asymmetric persistence.

The study by Santos, Lima, Freitas and Lima (2011) carried out an empirical-analytical research, with data collected in Economatica ${ }^{\circledR}$, with the non-financial companies listed on the BM\&FBovespa during the period from the first quarter of 2005 to the third quarter of 2009 to investigate whether the enactment of Law $11.638 / 07$ changed the degree of the sample's conditional accounting conservatism. For this verification, the authors used an adaptation of the model proposed by Basu (1997). After the data analysis, it was not possible to infer if the new rules have had some effect on the degree of asymmetric recognition of gains and losses.
The study by Hamdan, Abzakh and Al-Ataibi (2011) aims to assess the role of the public sector in the regulation of Accounting Standards in Kuwait to examine their ability to require the companies listed on the Kuwait Stock Exchange (KSE) to provide a reasonable level of conservatism accounting in preparing the financial statements. It analyses the factors that affect the level of accounting conservatism in companies referring to size, debt contracts, and the type of sector to which they belong, concluding that the companies with lower financial volume in their statements tend to present greater conservatism than the others.

Following the study by Santos et al. (2011) it is possible to identify other recent international and national studies. There are the international works produced by Xie, Zheng and Amy Lau (2012) that investigated the incentives in conservatism's tunneling accounting reports in the context of assets and equity and provided empirical evidence that accounting conservatism can be reported for opportunistic reasons rather than efficiency reasons; Kazemi, Hemmati and Faridvand (2011) investigated and confirmed by a quantitative analysis the relationship between earnings and conservative accounting, including persistence, predictability, relevance, value and opportunity; Dai and Ngo (2013) documented the positive association between political uncertainty and accounting conservatism; Asgari and Behpouri (2013) studied the effect of taxes on accounting conservatism in companies listed on the Tehran Stock Exchange, and concluded that there is a significant positive relationship between accounting conservatism and the tax burden applied to organizations; Ouyang and Wan (2014) studied the understanding of market analysts on accounting conservatism, concluding that short-term earnings forecasts of shareholders have conservatism similar to the net income presented, demonstrating further that as the forecast horizon increases the effects, the conservatism become weaker.

In addition, Brazilian researchers have produced the following works: Paulo, Cavalcante 
and Paulo (2013) verified the influence of several characteristics of auditing quality on the quality of accounting information, measured by conservatism, noting that the conservatism of accounting information is positively affected by the size of the auditing firm, and negatively affected by the time of auditors' service provision, the distance between the date of the opinion and the financial statements publication date; Brito, Lopes and Coelho (2013) investigated the presence of conditional conservatism in profits reported by financial institutions in Brazil, and examined whether this feature is different in state-owned banks and private banks, concluding it not to be possible to identify the presence of conservatism in profits reported by Brazilian banks, but identifying that stateowned institutions anticipate the recognition of unrealized losses.

\section{Methodology construction and analysis of conservatism presence}

The research was developed considering two directions: a) investigation of the presence of conservatism and change in corporate behavior through the Basu model (1997); b) analyses of the changes in the accounting indicators of current liquidity and indebtedness, in which it is expected to increase the former and reduce the latter. The methodological procedures and results of each test are presented in this topic.

\section{I Analysis of the presence of conservatism by Basu's model (1997)}

The research seeks to identify elements to evaluate changes in the behavior of companies regarding the accounting conceptual framework that removed the conservative forecast as characteristic of accounting information. According to Basu (1997:11), in the presence of conservatism the slope coefficient of a "regression of annual gains on annual unexpected returns is greater for negative returns than for positive unexpected returns". Thus, with the change in the conceptual framework, such behavior tends to change the slope of the regression, with a negative sign, bringing closer the effects of the positive and negative unexpected returns:

H1: In the presence of conservatism the slope coefficient of a regression of annual earnings on unexpected annual returns are higher for the negative unexpected returns than for positive unexpected returns in the period prior to the change of accounting conceptual framework, cancelled this effect in the period.

The econometric model developed by Basu (1997) is described as follows:

$X_{i t} / P_{i t-1}=\alpha_{0}+\alpha_{1} D R_{i t}+\beta_{0} R_{i t}+\beta_{1} R_{i t} D R_{i t}$

Where:

Xit is the company's earnings per share $i$ in the year $t$;

Pit-1 is the share price at the beginning of the period;

Rit is the company's return $i$ in the year $t$, calculated as follows: Pit-Pit-1/(Pit-1);

DRit is a dummy variable that assumes value 1 when Rit $<0$ and 0 in other situations.

In the presence of conservatism, the coefficient $\beta 1$ is expected to be positive and $\alpha 1$ negative, both statistically significant. As this research proposes to analyze the difference between the pre and post-change periods in the accounting standard, tests were carried out with the inclusion of a dummy variable, which assumes 1 for the years after the change in the accounting framework that removes conservatism as a characteristic of the accounting information, and 0 for previous years. The model can be thus expressed:

$X_{i t} / P_{i t-1}=\alpha_{0}+\alpha_{1} D R_{i t}+\beta_{0} R_{i t}+\beta_{1} R_{i t} D R_{i t}+\alpha_{2} D T_{i t}+\alpha_{3}$ $D T_{i t} D R_{i t}+\beta_{2} D T_{i t} R_{i t}+\beta_{3} D T_{i t} R_{i t} D R_{i t}$

The variable added to equation (1), $D T$, is a dummy type for period. It assumes value 1 
for years 2011 to 2013 and 0 for years prior to the change of the conceptual framework. By it is analyzed whether the effects of conservatism were stronger before the change in NBC TG. Thus, conservative behavior is expected to be reversed in relation to the initial period, with $\alpha 3$ positive and $\beta 3$ negative, indicating a reduction in the time of recognition of negative factors, namely eliminating the effect of conservatism

The earnings per share, as well as the returns and prices of the common shares of the companies listed on the BM\&FBovespa, were used not to differentiate oscillations in the companies for the traded share classes. Economatica ${ }^{\oplus}$ obtained the

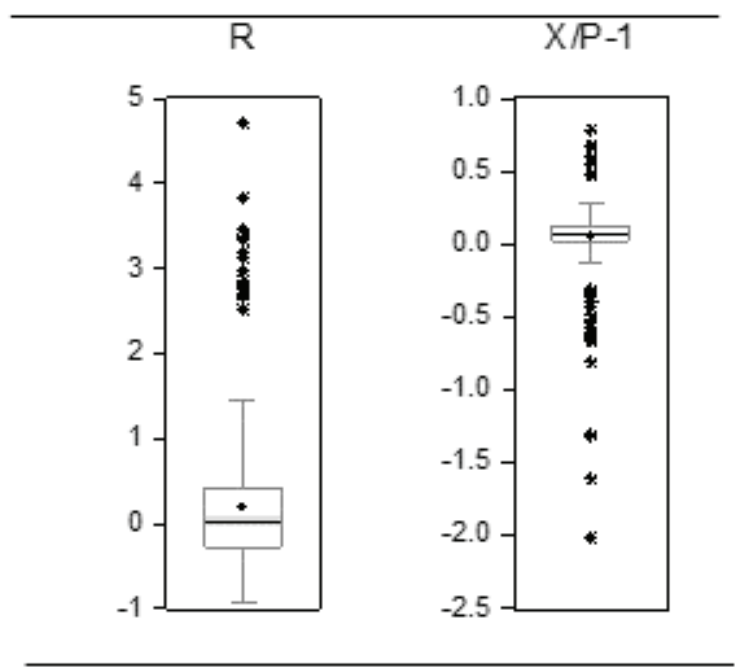

(a) Distant outliers

Figure 1. Sample Outliers.

Due to the nature of the data dispersion, both have a large number of abnormal observations. The decision to exclude only distant outliers from the range and maintain the number of observations to perform the analysis was based data for periods from 2008 to 2013, from 438 companies listed on BM\&FBovespa, on April 5, 2014. Of these, 355 presented data in the period, but 116 had data in all variables in each of the 6 periods analyzed. Thus, $\mathrm{i}=116$ and $\mathrm{t}=6$, with total $\mathrm{n}=696$ observations.

For regression analysis, atypical observations considered as distant outliers were suppressed by the graphic method (boxplot). For the dependent variable, the observation interval was greater than -0.3 and less than 0.42 . In the variable $\mathrm{R}$ the observations below 2.5 were maintained. Figure 1 illustrates the range of distant outliers in each variable.

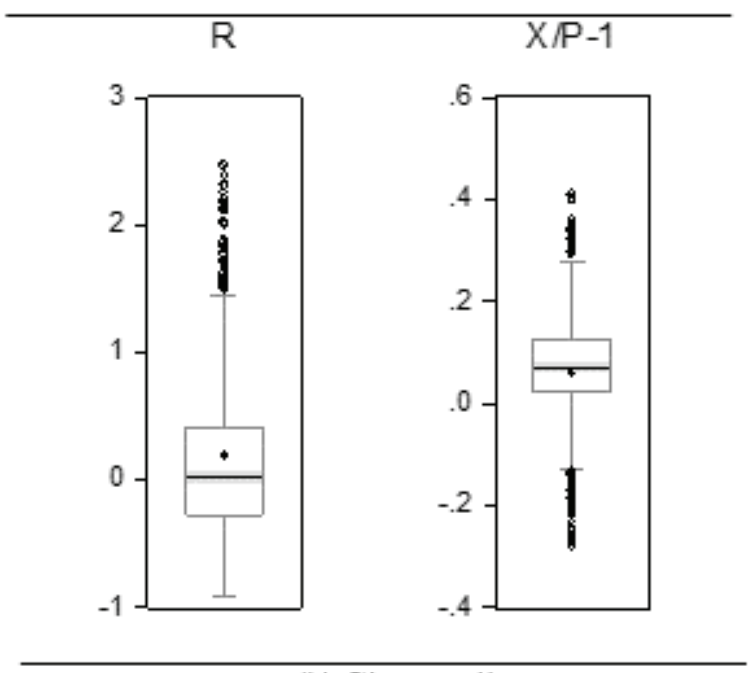

(b) Close outliers

on the natural behavior of variable data. At the end, the sample used $i=109$ and $t=6$, with total $\mathrm{n}=654$ observations. Both variables do not present normal distribution by the Jarque-Bera test, as presented in Table 1. 
Table 1

Descriptive statistics $n=654$

\begin{tabular}{|c|c|c|c|c|c|c|c|c|c|}
\hline $\mathrm{n}: 654$ & Mean & Median & Maximum & Minimum & $\begin{array}{l}\text { Standard } \\
\text { Deviation }\end{array}$ & Asymmetry & Kurtosis & $\begin{array}{c}\text { Jarque- } \\
\text { Bera }\end{array}$ & Prob. JB \\
\hline $\mathrm{X} / \mathrm{P}-1$ & 0.074 & 0.072 & 0.411 & -0.280 & 0.105 & -0.073 & 4.541 & 65.303 & 0.000 \\
\hline $\mathrm{R}$ & 0.128 & 0.019 & 2.484 & -0.914 & 0.609 & 1.185 & 4.820 & 243.247 & 0.000 \\
\hline \multicolumn{10}{|c|}{2008 a 2010; n:319 } \\
\hline $\mathrm{X} / \mathrm{P}-1$ & 0.096 & 0.085 & 0.411 & -0.266 & 0.107 & 0.099 & 4.011 & 14.109 & 0.001 \\
\hline $\mathrm{R}$ & 0.216 & 0.125 & 2.388 & -0.914 & 0.757 & 0.779 & 3.108 & 32.443 & 0.000 \\
\hline \multicolumn{10}{|c|}{2011 a $2013 ; n: 335$} \\
\hline $\mathrm{X} / \mathrm{P}-1$ & 0.052 & 0.060 & 0.409 & -0.280 & 0.099 & -0.386 & 5.052 & 67.078 & 0.000 \\
\hline $\mathrm{R}$ & 0.045 & -0.017 & 2.484 & -0.898 & 0.406 & 1.479 & 7.825 & 447.156 & 0.000 \\
\hline
\end{tabular}

The overall sample showed different average returns for recovery of the stock price (R) and profitability of shares (X/P-1), with averages of $12.8 \%$ and $7.4 \%$, respectively. This difference is higher from 2008 to 2010 and inverted from 2011 to 2013, in which the return for the accounting profit was greater than the stock price's appreciation return. Even with a higher average, $\mathrm{X} / \mathrm{P}-1$ presented a negative median, indicating that most of the observations presented negative returns, following the reduction of earnings per share, aligned behavior between accounting and capital market performance.

However, when analyzing such behavior, the data indicated a reduction in the relationship between the market performance and the companies' accounting result in 2011. In the correlation between the variables, the complete sample presented a significant and positive relationship $\mathrm{r}=0.4088(\mathrm{t}=11.436 ; \mathrm{p}<0.001)$, higher in the first period, $r=0.449(t=8.937$; $\mathrm{p}<0.001)$, dropping after 2011, $\mathrm{r}=0.323(\mathrm{t}=6.238$; $\mathrm{p}<0.001)$.

Table 2 presents the regression results of the model, with fixed effects in the data panel, using White's consistent matrix. Hausman's test presented a Chi-square $=28.847$ value, significant at $0.1 \%$, rejecting the null hypothesis of no significant difference between the fixed effects model estimators of the error component model. Thus, the use of fixed effects in panel data is appropriate to the model.

Table 2

Linear regression - data panel with fixed effects - Dependent variable $X / P_{t-1}$

\begin{tabular}{lcccccc}
\hline Variable & Coefficients & Relation found & $\begin{array}{c}\text { Expected } \\
\text { relation }\end{array}$ & $\begin{array}{c}\text { Standard } \\
\text { Deviation }\end{array}$ & t-statistic & Prob. t \\
\hline $\mathrm{C}$ & $\alpha_{0=} 0,079$ & + & $?$ & 0.009 & 23.364 & 0.000 \\
$\mathrm{DR}$ & $\alpha_{1=} 0,025$ & + & - & 0.015 & 3.170 & 0.002 \\
$\mathrm{R}$ & $\beta_{0=} 0,061$ & + & + & 0.009 & 26.960 & 0.000 \\
$\mathrm{DR} * \mathrm{R}$ & $\beta_{1=} 0,036$ & + & + & 0.025 & 2.840 & 0.005 \\
$\mathrm{DT}$ & $\alpha_{2=}=0,014$ & - & $?$ & 0.012 & -1.903 & 0.058 \\
$\mathrm{DR}{ }^{*} \mathrm{DT}$ & $\alpha_{3=}=0,044$ & - & + & 0.020 & -2.985 & 0.003 \\
$\mathrm{R}^{*} \mathrm{DT}$ & $\beta_{2=}=0,032$ & - & $?$ & 0.019 & -2.230 & 0.026 \\
$\mathrm{DR} * \mathrm{R}^{*} \mathrm{DT}$ & $\beta_{3=}=0,009$ & - & - & 0.045 & -0.364 & 0.716 \\
\hline
\end{tabular}


The Durbin-Watson statistic presented Chi-square value $=1.90$, falling into the zone of non-rejection of the null hypothesis of absence of autocorrelation. The Breusch-Pagan-Godfrey test for heteroscedasticity showed Chi-square $=25.55$, not higher than the critical value of Chisquare $=67.33$, not rejecting the null hypothesis of homoscedasticity. Table 2 shows that test $f$ and values of test $t$ of the constant of the other variables, except for $\mathrm{DR}^{*} \mathrm{R}^{*} \mathrm{DT}$, were significant. The coefficient of determination (adjusted R2) indicates that $56.51 \%$ of the total variance of profitability by accounting profit per share (X/ Pt-1) is explained by the analyzed model.

Contrary to expectations, the distribution of residues is considered non-normal by the Jarque-Bera test. However, based on the nature of the data (X/Pt-1 variable data distribution), the general analysis of the model and the tests of the linear regression assumptions, the coefficients found are the real estimators of the equation, even if they cannot be considered the best nonbiased estimators (Gujarati, 2006); therefore, the statistical test was maintained. Thus, we do not make statistical inferences and test hypotheses about the sample data; rather, we use the analysis about the estimation of the Basu model (1997).

The $\mathrm{R}$ relation with $\mathrm{X} / \mathrm{Pt}-1$ was positive and significant, indicating that the stock price return is related to the return of net income shares. The coefficients that determine the behavior of companies in the face of conservatism were partially identified. $\alpha 1$ showed a significant and positive relationship indicating that negative effects are absorbed at different level of positive effects, although a negative relationship was expected. $\beta 1$ was positive and significant, demonstrating that variations in net income are faster in the presence of negative effects when facing positive effects. Thus, the sample data demonstrate the presence of conservatism in accounting profit by faster absorption of negative effects than of positive effects.

The period from 2008 to 2010 is distinguished by the adoption of IFRS
(International Financial Reports Standards) accounting standards. As identified by Alves and Martinez (2014) and Sousa, Sousa and Demonier (2016), the adherence to this standard did not alter the effect of conservatism in companies when compared to previous periods. Additional testing segregating the effect for post-full adherence years, 2010-2013, did not alter the meaning and statistical significance of the previously seen regressors and did not reveal results statistically significant.

As for the alteration made in the accounting conceptual framework, analyzed by the coefficients $\alpha 3$ and $\beta 3$, no evidence was identified pointing to changes in the accounting information of the characteristics of the sample companies. Hence, even $\beta 3$ presenting the expected negative relation is not statistically significant, not confirming changes in the levels of conservatism of the companies analyzed after changes in NBC TG. Therefore, additional tests were performed and discussed in the next section.

\subsection{Conservative analysis by the behavior of accounting indicators}

Additional tests were completed on two accounting indicators that suggest modifications in the companies' behavior regarding the change in the accounting framework. The analysis had abnormal changes for the years 2011, the first year in which the adoption of the new conceptual framework was forecasted, and 2012, due to possible adjustments not performed in the first year. Hence, the effect of conservatism withdrawal was analyzed by the following behaviors:

a) Current liquidity: the absence of conservatism can result in abnormal increases in this indicator in 2011 and 2012, when compared to other periods. This can be a result, for example, of the postponement of losses on receivables, inventory maintenance items with low level of sales in the face of equally valid options.

b) Indebtedness: the expected behavior in the absence of conservatism is the reduction of levels of indebtedness in 2011 and 2012, when 
compared to other years. Changes in the level of indebtedness may be the result of choices about provisions for losses with future payments of lower value, as well as post-fixed rates of financing at lower levels.

Data was collected from Economatica ${ }^{\circ}$ basis for the periods 2008-2013, having as starting point the companies listed on the BM\&FBovespa on April 5, 2014, for 438 companies. The final number of companies and observations and the results of the statistical tests are presented, as follows.

\section{Current Liquidity}

The current liquidity indicator (LCit) represents the company's ability to pay in the short term, considering elements of current asset (ACit) and current liabilities (PCit) of company $i$ at time $t$. It may be expressed as follows:

$$
L C_{i t}=A C_{i t} / P C_{i t}
$$

In the absence of conservatism, assets are expected to be overvalued and liabilities are undervalued. Thus, the behavior of the indicator would increase abnormally in relation to periods in which conservatism determines the accounting information.

H2: With the withdrawal of conservatism from the accounting framework, the average levels of the companies' current liquidity reveal abnormal increases in the first few years.

Descriptive statistics, the correlation of companies' liquidity in different years, and the Wilcoxon test were analyzed to evaluate the significance of the median differences. Among the 438 listed companies, 353 presented current liquidity data from 2008 to 2013. For analysis, the cases with no information in at least one of the periods and the exclusion of financial companies reduced the sample to 271 companies. As outliers $(i=126)$ we considered the observations, for each year, of the values in the first and last percentile. At the end, we used data (i) from 145 companies in $(\mathrm{t}) 6$ years $(\mathrm{n}=870)$.

Table 3

\section{Descriptive statistics}

\begin{tabular}{lcccccc}
\hline & LC2008 & LC2009 & LC2010 & LC2011 & LC2012 & LC2013 \\
\hline Mean & 1.544 & 1.558 & 1.586 & 1.520 & 1.495 & 1.353 \\
Median & 1.351 & 1.361 & 1.445 & 1.379 & 4.552 & 1.336 \\
Maximum & 4.505 & 4.502 & 4.333 & 4.030 & 058 & 4.265 \\
Minimum & 0.438 & 0.431 & 0.431 & 0.353 & 0.369 & 0.219 \\
Standard Deviation & 0.814 & 0.840 & 0.792 & 0.748 & 0.755 & 0.851 \\
Jarque-Bera & 1.544 & 1.558 & 1.586 & 1.520 & 1.495 & 1.552 \\
Prob. JB & 1.351 & 1.361 & 1.445 & 1.379 & 1.353 & 1.336 \\
\hline
\end{tabular}

By organizing the data of each period as a different variable, it was possible to analyze the descriptive statistics and the correlation between the liquidity indexes in each year. It is possible to observe certain regularity in the behavior of the mean, with reduction in the years 2011 and 2012, after the change of the conceptual framework. However, in 2013, the level was similar as in the years that predicted conservatism. Contrary to expectations, the mean was lower in the period without conservatism compared to the years prior to 2011. Since the data presented an abnormal distribution by the Jarque-Bera test, we used Spearman's correlation analysis, according to Table 4. 
Table 4

Spearman's correlation analysis - Current liquidity

\begin{tabular}{lccccc}
\hline $\mathbf{n}=177$ & LC2008 & LC2009 & LC2010 & LC2011 & LC2012 \\
\hline LC2009 & $0.780^{*}$ & & & \\
LC2010 & $0.643^{*}$ & $0.730^{*}$ & & \\
LC2011 & $0.688^{*}$ & $0.714^{*}$ & $0.752^{*}$ & & \\
LC2012 & $0.583^{*}$ & $0.602^{*}$ & $0.683^{*}$ & $0.738^{*}$ & $0.782^{*}$ \\
LC2013 & $0.541^{*}$ & $0.601^{*}$ & $0.670^{*}$ & $0.680^{*}$ & 0 \\
\hline
\end{tabular}

Note. ${ }^{*}$-value $<0.01 \%$

As expected, all data presented in Table 4 have high correlation value, especially in immediately related years; all are significant at $0.1 \%$. However, there is no change in behavior over the period, when analyzed in 2011 and 2012. Thus, the correlation between the periods, by the current liquidity variable, does not present evidence of changes in the behavior of the companies after the change in the conceptual accounting framework.

Data were also submitted to the Wilcoxon test, as evidence of changes is sought in company behavior comparing data from different periods in paired samples. The results are shown in Tables 5 and 6.

Table 5

Wilcoxon's test results - Current liquidity

\begin{tabular}{|c|c|c|c|c|}
\hline Periods & Ranks & $\mathbf{N}($ total $=177)$ & Mean & Sum \\
\hline \multirow[t]{3}{*}{ LC2009 - LC2008 } & Negative posts & $73^{a}$ & 70.26 & 5,129 \\
\hline & Positive posts & $72^{\mathrm{b}}$ & 75.78 & 5,456 \\
\hline & Relations & $0^{c}$ & & \\
\hline \multirow[t]{3}{*}{ LC2010 - LC2009 } & Negative posts & $66^{\mathrm{d}}$ & 70.30 & 4,640 \\
\hline & Positive posts & $79^{\mathrm{e}}$ & 75.25 & 5,945 \\
\hline & Relations & $0^{\mathrm{f}}$ & & \\
\hline \multirow[t]{3}{*}{ LC2011 - LC2010 } & Negative posts & $75^{g}$ & 79.16 & 5,937 \\
\hline & Positive posts & $70^{\mathrm{h}}$ & 66.40 & 4,648 \\
\hline & Relations & $0^{\mathrm{i}}$ & & \\
\hline \multirow[t]{3}{*}{ LC2012 - LC2011 } & Negative posts & $83^{j}$ & 71.40 & 5,926 \\
\hline & Positive posts & $62^{\mathrm{k}}$ & 75.15 & 4,659 \\
\hline & Relations & $0^{1}$ & & \\
\hline \multirow[t]{3}{*}{ LC2013 - LC2012 } & Negative posts & $70^{\mathrm{m}}$ & 71.49 & 5,004 \\
\hline & Positive posts & $75^{\mathrm{n}}$ & 74.41 & 5,581 \\
\hline & Relations & $0^{\circ}$ & & \\
\hline
\end{tabular}

Note. A. LC2009 < LC2008; b. LC2009 > LC2008; c. LC2009 = LC2008; d. LC2010 < LC2009; e. LC2010 > LC2009; f. LC2010 = LC2009; g. LC2011 < LC2010; h. LC2011 > LC2010; i. LC2011 = LC2010; j. LC2012 < LC2011; k. LC2012 > LC2011; 1. LC2012 = LC2011; m. LC2013 < LC2012; n. LC2013 > LC2012; o. LC2013 = LC2012 
Table 6

Statistic ${ }^{\mathrm{c}}$ tests

\begin{tabular}{lccccc}
\hline & $\begin{array}{c}\text { LC2009 } \\
\text { LC2008 }\end{array}$ & $\begin{array}{c}\text { LC2010 - } \\
\text { LC2009 }\end{array}$ & $\begin{array}{c}\text { LC2011 - } \\
\text { LC2010 }\end{array}$ & $\begin{array}{c}\text { LC2012 - } \\
\text { LC2011 }\end{array}$ & $\begin{array}{c}\text { LC2013 - } \\
\text { LC2012 }\end{array}$ \\
\hline Z & $-0.323^{\mathrm{a}}$ & $-1.288^{\mathrm{a}}$ & $-1.272^{\mathrm{b}}$ & $-1.250^{\mathrm{b}}$ & $-0.569^{\mathrm{a}}$ \\
Signif. Exact (two-tailed) & 0.749 & 0.199 & 0.204 & 0.212 & 0.571 \\
Signif. Exact (one tailed) & 0.374 & 0.099 & 0.102 & 0.106 & 0.285 \\
Probability & 0.001 & 0.000 & 0.000 & 0.000 & 0.001 \\
\hline
\end{tabular}

Note. a. Based on negative posts; b. Based on positive posts; c. Signs of the Wilcoxon Test Stations

The Wilcoxon test has as null hypothesis the equality in the behavior of the sample variables. The data indicates that there are no elements to reject this hypothesis; there was no change in the liquidity behavior that could indicate a statistically significant increase or decrease. Thus, $\mathrm{H} 2$ in this research is not confirmed, as it is not possible to reject the null hypothesis, equal in the behavior of liquidity in the years following the change of the conceptual framework. This result corroborates with the previous test, and does not identify a change in accounting practices capable of eliminating the effect of conservatism in accounting.

\section{Indebtedness}

The indebtedness indicator (Endit) represents the total debt level of the companies in relation to their total liabilities, composed of the liabilities ((PExit) and the shareholders' equity (PLit) of company $i$ at time $t$, as follows:

$$
E n d_{i t}=P E x_{i t} /\left(P E x_{i t}+P L_{i t}\right)
$$

In the absence of conservatism, it is expected that elements of the Liabilities will be undervalued, whereas the Shareholders'
Equity has overvalued elements, such as retained earnings. Thus, the behavior of the indicator would be an abnormal reduction in relation to periods in which conservatism is the determinant of the accounting information.

H3: With the withdrawal of conservatism from accounting's conceptual framework, the average levels of companies' indebtedness have abnormal reductions in the early years.

To analyze this behavior, we considered the descriptive statistics data, correlation of indebtedness of companies in different years and the $t$ test to assess the significance of mean differences. Among the 438 listed companies, 268 presented current liquidity data from 2008 to 2013. For analysis, the cases with lack of information in at least one of the periods and the exclusion of financial companies reduced the sample to 184 companies. As outliers ( $\mathrm{i}=80$ ), we considered the observations for each year of the values in the first and last percentile (Table 7). At the end, data from 104 companies (i) were used in $(\mathrm{t}) 6$ years $(\mathrm{n}=624)$. 
Table 7

\section{Descriptive statistics}

\begin{tabular}{lllllll}
\hline & End2008 & End2009 & End2010 & End2011 & End2012 & End2013 \\
\hline Mean & 26.758 & 25.691 & 25.233 & 26.636 & 27.584 & 28.337 \\
Median & 26.581 & 24.765 & 24.008 & 25.948 & 27.060 & 27.604 \\
Maximum & 55.610 & 51.318 & 43.178 & 48.169 & 51.271 & 54.040 \\
Minimum & 4.587 & 7.785 & 6.847 & 9.101 & 9.439 & 9.247 \\
Standard Deviation & 11.401 & 9.714 & 9.463 & 9.313 & 9.779 & 10.467 \\
Jarque-Bera & 26.758 & 25.691 & 25.233 & 26.636 & 27.584 & 28.337 \\
Prob. JB & 26.581 & 24.765 & 24.008 & 25.948 & 27.060 & 27.604 \\
\hline
\end{tabular}

The mean's behavior indicates a rise in indebtedness from 2011, contrary to expectations. Moreover, it is another indication of the absence of changes in the behavior of companies referring to conservatism. The correlation analysis is expected to become weaker for the years 2010-2011 and/or 2011-2012, in the event of accounting information changes, because of the absence of the conservatism characteristic.

Table 8

\section{Spearman's correlation analysis - Indebtedness}

\begin{tabular}{llllll}
\hline $\mathbf{n}=109$ & End2008 & End2009 & End2010 & End2011 & End2012 \\
\hline End2009 & $0.774^{*}$ & & & & \\
End2010 & $0.677^{*}$ & $0.746^{*}$ & & & \\
End2011 & $0.465^{*}$ & $0.542^{*}$ & $0.785^{*}$ & & \\
End2012 & $0.323^{*}$ & $0.405^{*}$ & $0.655^{*}$ & $0.865^{*}$ & \\
End2013 & $0.171^{* *}$ & $0.261^{*}$ & $0.360^{*}$ & $0.595^{*}$ & $0.676^{*}$ \\
\hline
\end{tabular}

Note. ${ }^{*}$ p-valor $<0.01 \% ;{ }^{* *}$ p-valor $<0.1 \%$

As expected, the indebtedness of period $\mathrm{t}$ is highly correlated to period $\mathrm{t}-1$, significant at $0.01 \%$. However, the behavior of the variables over time revealed no change in the result of correlation analysis, as shown in Table 6. Thus, there was no change in the correlation coefficient that promotes alteration in the indicator's behavior. The indebtedness data of all the periods presented normal distribution by the JarqueBera test, so that the indebtedness behavior was analyzed by Test $\mathrm{t}$ (Table 9).

Table 9

Test results paired $t$ - Indebtedness $-\mathbf{g l}=103$

\begin{tabular}{llllclc}
\hline Pair & & Mean $_{\mathrm{t}-1}$ & Mean $_{\mathbf{t}}$ & $\begin{array}{c}\text { Difference } \\
\text { between means }\end{array}$ & t $^{\text {Sig. (two-tailed) }}$ \\
\hline Pair 1 & End2008 - End2009 & 26.758 & 25.691 & 1.067 & 1.495 & 0.138 \\
Pair 2 & End2009 - End2010 & 25.691 & 25.233 & 0.458 & 0.683 & 0.496 \\
Pair 3 & End2010 - End2011 & $\mathbf{2 5 . 2 3 3}$ & $\mathbf{2 6 . 6 3 6}$ & $\mathbf{- 1 . 4 0 3}$ & $\mathbf{- 2 . 3 2 5}$ & $\mathbf{0 . 0 2 2}$ \\
Pair 4 & End2011 - End2012 & $\mathbf{2 6 . 6 3 6}$ & $\mathbf{2 7 . 5 8 4}$ & $\mathbf{- 0 . 9 4 8}$ & $\mathbf{- 1 . 9 4 2}$ & $\mathbf{0 . 0 5 5}$ \\
Pair 5 & End2012 - End2013 & 27.584 & 28.337 & -0.753 & -0.939 & 0.350 \\
\hline
\end{tabular}


The results presented by Test $\mathrm{t}$ show that the fluctuations in the behavior of the indebtedness are statistically significant with the increase of their levels in the years following the alteration of the conceptual framework. For 2010-2011, the ratio is significant at 5\% and 2011-2012 at $10 \%$. Thus, we reject the null hypothesis that the debt behavior is the same compared in both years when pairs 3 and 4 are analyzed. Thus, contrary to the expectations of this research, the debt was not affected by the absence of conservatism, but by factors unrelated to the object of this research. In both periods, there was an increase in this indicator while expectations fell to its reduction; there is no indication of changes in accounting practices.

\section{Review}

In the first part of the result analysis, section 3.1, tests with data from 109 companies indicated the presence of conservatism in the sample from 2008 to 2013, confirming the expectation. Additionally, the effects of positive and negative returns were expected to be statistically the same for the years following the change in accounting pronouncement, indicative of the annulment of the impacts of conservatism. However, the data did not confirm changes in company behavior as of 2011, showing that the accounting information continued to reflect the effects of conservatism. Additional analyzes of changes in the behavior of accounting indicators (liquidity and indebtedness), over which are assumed alterations in the absence of conservatism, showed results that confirm the absence of changes in the behavior of companies as of 2011 .

Referring to the Santos et al. (2011) work, a difference in the findings may be observed. While no conservative effects were found in quarterly data, the findings identified here revealed conservatism throughout the period, based on annual data. Both have periods of 2008 and 2009 in common and such differences may be the result of quarterly intervals from the study by Santos et al. (2011). In addition to the difference between the total periods analyzed, the time between the news and the reflection in the accounting data released quarterly or annually, as well as changes recommended by auditing on the partial (quarterly) and final (annual) financial statements may have caused such a difference.

Regarding the presence of conservatism from 2011, these findings may be the result of behaviors similar to other samples. From 2008, compared to the international crisis, these companies may have chosen to maintain the level of conservatism on higher levels of economic uncertainty. Particularly, Dai and Ngo (2013) identified political uncertainty with the presence of conservatism.

However, the presence of conservatism in the accounting information of the sample contradict the study of Santos et al. (2011). This variation can be explained by the difference in the analysis periods of the studies, having in common only the years 2008 and 2009. Variations in the sample concerning the exclusion of financial companies in Santos, Lima, Freitas and Lima (2011) and the absence of the search for the moderating effects of the variable indicative of the quarterly effects (DT) on the DR and $\mathrm{R}$ variables in the 2011 study.

Furthermore, in the companies operating in Brazil, the tax burden may be responsible for a higher level of conservatism, acting as a form of tax planning. Lower levels of profit, resulting from the application of prudence, would incur in a lower tax burden. This association was identified in Asgari and Behpouri (2013) related to the Iranian stock exchange, and may be an explanatory factor for the absence of change in the companies' behavior.

Another element discussed is the absence of mechanisms capable of recognizing divergent behaviors to those postulated by accounting standards. Thus, if the economic interest is higher, such as the reduction of the tax burden, opportunistic behavior may interfere in the neutrality of the accounting information, impairing its quality. 


\section{Conclusion}

This research investigated whether the Brazilian Accounting Standard that regulates the conceptual framework for the preparation and disclosure of the accounting and financial report (NBC TG), altered in 2011, which excludes Prudence or Conservatism from the qualitative characteristics of accounting, caused effects on accounting information of companies listed on BM\&FBovespa. Therefore, companies' data from 2008, collected from the Economatica ${ }^{\circledR}$ database, were analyzed through three research hypotheses.

Initially, analyzing the Basu model (1997), Hypothesis 1, on the presence of conservatism was partially confirmed, and there was no evidence capable of confirming the change in behavior in the accounting information with the withdrawal of conservatism as a characteristic of the accounting information. For Hypotheses 2 and 3, the change in the behavior of the accounting indicators of liquidity and indebtedness, respectively, was analyzed. With the withdrawal of conservatism, an increase in liquidity and reduction in indebtedness was expected at abnormal levels for years 2011 and/or 2012 in relation to the other periods. The tests did not present elements capable of confirming such hypotheses, corroborating with Hypothesis 1, that there was no influence of the change in the Brazilian accounting framework in company information.

Thus, the expected alteration from the change in the accounting framework, aiming to promote neutrality as quality of accounting information through the withdrawal of conservatism, was not confirmed. Therefore, because of the findings of this research, analyzes on the financial statements should not assume neutrality in the information disclosed, since both before and after the withdrawal of prudence as a qualitative aspect of accounting information the standards remain the same, tending to a possible consolidated bias in market practices.
The study serves as an alert for market analysts, stockbrokers, companies, market regulators, indicating a possible formalization practiced by the companies.

In addition, these findings have implications for the analysis of Brazilian accounting standards, such as CPC and CFC, regarding the adoption of the required accounting practices and their effects on company information. For the literature, it reinforces the perception of the superiority of the economic interest, especially for possible tax gains, to the detriment of the quality of the accounting information, whether it is normative regulation effect or of another origin. Thus, it aligns itself to the studies on the effects of normative changes without mechanisms that guarantee their fulfillment.

However, the reasons why companies maintain this behavior referring to their financial information were not analyzed, resulting in an opportunity for research, through surveys or case studies to identify them. We also suggest studies that seek to identify the effects of maintaining conservatism on the perceptions of financial analysts and/or other market regulators, as well as identifying the practices of accountants regarding them.

\section{References}

Alves, J. de S., \& Martinez, A. L. (2014). Efeitos da adoção das IFRS no conservadorismo contábil nas sociedades de grande porte. Advances in Scientific and Applied Accounting, 7(2), 224-243.

Asgari, M., \& Behpouri, M. (2013). Investigating the effect of tax costs on accounting conservatism: evidence from Tehran Stock Exchange. Management Science Letters, 4, 5-10.

Basu, S. (1997). The conservatism principle and the asymmetric timeliness of earnings. 
Journal of Accounting and Economics, 24, 3-17.

Basu, S. (2009). Conservatism research: historical development and future prospects. China Journal of Accounting Research, 2 (1), 1-20.

Brito, G. A. S., Lopes, A. B., \& Coelho, A. C. D. (2012, October-December). Conservadorismo dos lucros contábeis dos bancos no Brasil: a influência do controle estatal. Revista Universo Contábil, 8(4), 1939. Blumenau.

CFC - Conselho Federal de Contabilidade (2011). Resolução CFC N.o 1.374/11. Brasília.

CPC - Comitê de Pronunciamentos Contábeis (2011, dezembro). Pronunciamento conceitual básico (R1): estrutura conceitual para elaboração e divulgação de relatório contábil-financeiro.

Crawdford, S. S., Rountree, B, \& Price, R. (2010, October). Regulation and accounting conservatism. Jones Graduate School of Business. Rice University. Disponível em http://www.kellogg.northwestern.edu/ accounting/papers/rountree.pdf. Acesso em 04 abril de 2014.

Dai, L., \& Ngo, P. (2013). Political uncertainty and accounting conservatism: evidence from the U.S. presidential election cycle. Munich Personal RePec Archive, n. 43796.

FASB - Financial Accounting Standards Board (2008). Statement of financial accounting concepts no. 2 - qualitative characteristics of accounting information.

Hamdan, A. M, Abzakh, M. H., \& Al-Ataibi, M. H. (2011). Factors influencing the level of accounting conservatism in the financial statements. International Business Research, 4(3).
Hendriksen, E. (1982). Accounting theory (4th edition). Irwin: Illinois.

IASB - International Accounting Standards Board (2005). Conceptual framework qualitative characteristics 1: relevance and reliability. London.

Iudícibus, S. (2009). Teoria da contabilidade (9a edição). São Paulo: Atlas.

Kan, V. (1990). Accounting Theory (2th edition). John Wiley \& Sons: New York.

Kazemi, H., Hemmati, H., \& Faridvand, R. (2011). Investigating the relationship between conservatism accounting and earnings attributes. World Applied Sciences Journal, 9(12), 1385-1396.

Mattessich, R. (1964, October). Accounting and analytical methods. Richard D. Irwin, Inc.: Illinois.

Ouyang, B., Wan, H. (2014). Do analysts understand conservatism? Accounting and Finance Research, 3(1).

Paulo, I. I. S. L. de M., Cavalcante, P. R. N., \& Paulo, E. (2013, July-September). Relação entre qualidade da auditoria e conservadorismo contábil nas empresas brasileiras. Revista de Educação e Pesquisa em Contabilidade, 7(3), 305-327. Brasília.

Santos, L. P. G., Lima, G. A. S. F. de, Freitas, S. C. de, \& Lima, I. S. (2011, MayAugust). Efeito da lei 11.638/07 sobre o conservadorismo condicional das empresas listadas BM\&FBOVESPA. Revista de Contabilidade \& Finanças, 56(22), 174-188.

Sousa, E. F. de, Sousa, A. F., \& Demonier, G. B. (2016). Adoção das IFRS no Brasil: efeitos no conservadorismo contábil. REPEC - Revista de Educação e Pesquisa em Contabilidade, 10(2), 136-147. 
Watts, R. L. (2003a, September). Conservatism in accounting - part I: explanations and implications. Accounting Horizons, 3(17), 207-221.

Watts, R. L. (2003b, December). Conservatism in accounting - part II: evidence and research opportunities. Accounting Horizons, 4(17), 287-301.

Xie, Y., Zheng, L., \& Amy Lau, H.L. (2012) Reporting incentives for accounting conservatism, evidence from asset and equity tunneling. Pacific Accounting Review, 24(2), 38-160.

\section{About the authors:}

1. Clóvis Antônio Kronbauer, PhD in Accounting and Auditing, University of Seville, Spain.

E-mail: clovisk@unisinos.br.

2. Luiz Henrique Figueira Marquezan, PhD in Accounting Sciences, University of Vale do Rio dos Sinos, Brazil. E-mail: luizmarquezan@gmail.com.

3. Marco Aurélio Gomer Barbosa, Master in Accounting Sciences, University of Vale do Rio dos Sinos, Brazil. E-mail: marcobarbosa@furg.br.

4. Carlos Alberto Diehl, PhD in Production Engineering, Federal University of Santa Catarina, Brazil.

E-mail: cd@unisinos.br.

\section{Contribution of each author:}

\begin{tabular}{|c|c|c|c|c|}
\hline Contribution & $\begin{array}{l}\text { Clóvis Antônio } \\
\text { Kronbauer }\end{array}$ & $\begin{array}{c}\text { Luiz Henrique } \\
\text { Figueira } \\
\text { Marquezan }\end{array}$ & $\begin{array}{c}\text { Marco Aurélio } \\
\text { Gomer } \\
\text { Barbosa }\end{array}$ & $\begin{array}{l}\text { Carlos } \\
\text { Alberto Diehl }\end{array}$ \\
\hline 1. Definition of research problem & $\sqrt{ }$ & $\sqrt{ }$ & $\sqrt{ }$ & $\sqrt{ }$ \\
\hline $\begin{array}{l}\text { 2. Development of hypotheses or research questions } \\
\text { (empirical studies) }\end{array}$ & $\sqrt{ }$ & $\sqrt{ }$ & $\sqrt{ }$ & $\sqrt{ }$ \\
\hline \multicolumn{5}{|c|}{ 3. Development of theoretical propositions (theoretical Work) } \\
\hline 4. Theoretical foundation/ Literature review & $\sqrt{ }$ & & $\sqrt{ }$ & $\sqrt{ }$ \\
\hline 5. Definition of methodological procedures & & $\sqrt{ }$ & $\sqrt{ }$ & \\
\hline 6. Data collection & & $\sqrt{ }$ & & \\
\hline 7. Statistical analysis & & $\sqrt{ }$ & & \\
\hline 8. Analysis and interpretation of data & $\sqrt{ }$ & $\sqrt{ }$ & $\sqrt{ }$ & $\sqrt{ }$ \\
\hline 9. Critical revision of the manuscript & $\sqrt{ }$ & $\sqrt{ }$ & $\sqrt{ }$ & $\sqrt{ }$ \\
\hline 10. Manuscript Writing & & $\sqrt{ }$ & $\sqrt{ }$ & \\
\hline
\end{tabular}

